\title{
The Effects of Mitochondrial mt4977 Deletion on Platelet Function in Ischemic Heart Disease Patients
}

\author{
İskemik Kalp Hastalarında Trombosit Fonksiyonu Üzerine Mitokondri mt4977 Delesyonunun Etkileri
}

\author{
Ahmet Ozaydin', ID Ayla Kerimova ${ }^{2}$, iD Ilhan Onaran² \\ 1-Department of Medical Genetics, Cerrahpasa Faculty of Medicine, Istanbul University-Cerrahpasa, Istanbul. \\ 2-Department of Medical Biology, Cerrahpasa Faculty of Medicine, Istanbul University-Cerrahpasa, Istanbul.
}

\begin{abstract}
Objective: It is known that point mutations, duplications and deletions occur in mitochondrial DNAs (mtDNA) of different tissues of individuals. Among the deletions observed, mt4977 mutation, which is located at nucleotide positions 8470-8482 and 13447-13459 and causes the loss of 4977 base pairs, is the most common. mtDNA 4977 deletion leads to the loss of 8 genes encoding subunits of respiratory chain complexes. Consequently, the deletion could be expected to inhibit the oxidative function and reduce ATP production level. It is known that mitochondrial ATP production has an important role on platelet functions. However, there is no information about this in the literature. Since platelet activation in ischemic heart disease (IHD) has been shown to play an important role in the pathophysiology of the disease, we wanted to examine the relationship between platelet function and mtDNA 4977 deletion in ischemic heart disease.

Material and Method: Platelet functions were studied by giving ADP stimulus with the help of lumiaggregometer device to evaluate in terms of secretion and aggregation. ATP measurement was performed with the bioluminescence assay kit. mtDNA 4977 deletion was determined by the modified simultaneous quantitative polymerase chain reaction method.

Results: The frequency of mtDNA 4977 deletion and mtDNA copy number were higher in platelets of the patients compared with the healthy control group $(p<0.05)$. However, no significant differences in platelet ATP content, and in their slope $(\Omega)$ and \% amplitude values were observed between both groups $(p>0.05)$.

Conclusion: It was observed that increased deletion in patients with IHD did not have a significant effect on platelet dysfunction compared with healthy control subjects.

ÖZET

Amaç: Bireylerin farkl dokularındaki mitokondriyal DNA'larında (mtDNA) nokta mutasyonları, duplikasyonlar ve delesyonlar meydana geldiği bilinmektedir. Gözlenen delesyonlar içerisinde 8470-8482 ile 13447-13459 nükleotid pozisyonlarında yer alan ve 4977 baz çiftinin kaybına yol açan mtDNA 4977 mutasyonu en sık olarak görülmtedir. mtDNA 4977 delesyonu solunum zinciri komplekslerinin alt ünitlerini kodlayan 8 genin kaybolmasina yol açar. Buna bağlı olarak delesyonun oksidatif fonksiyonu engellemesi ve ATP üretim düzeyini azaltması beklenebilir. Mitokondriyal ATP üretiminin trombosit fonksiyonları üzerinde önemli bir rolü olduğu bilinmektedir. Ancak bununla ilişkili olarak literatürde herhangi bir bilgi göze çarpmamaktadır. İskemik kalp hastalı̆̆ında (iKH) trombosit aktivasyonunun hastallk fizyopatolojisinde önemli bir rol oynadı̆̆ gösterildiğinden, bu çallş̧mamızda trombosit fonksiyonu ile mtDNA 4977 delesyonu arasındaki iliskiyi ve iskemik kalp hastalığı gelișimindeki olası etkilerini araştırmayı amaçladık.

Gereç ve Yöntem: Trombosit fonksiyonları, sekresyon ve agregasyon açısından değerlendirilmek üzere lumiagregometre cihazı yardımı ile ADP uyaranı verilerek çalışıldı. ATP ölçümü biyolüminesans test kiti ile yapıldı. mt4977 delesyonu, modifiye edilmiş eşzamanl kantitatif polimeraz zincir reaksiyonu (RT-PCR) yöntemi ile belirlendi.

Bulgular: Hastaların trombositlerinde mtDNA 4977 delesyon sikliğı ve mtDNA kopya saylsı sağllklı kontrol grubuna göre daha yüksekti $(p<0.05)$. Ancak her iki grup arasında trombosit ATP içeriği ile bunların eğim $(\Omega)$ ve \% amplitüd değerlerinde anlaml farklllk gözlenmedi $(p>0.05)$.

Sonuç: Sağllklı kontrol denekleriyle karşılaştırıldığında, IKH hastalarında artmış delesyonun trombosit disfonksiyonu üzerinde anlamlı bir etkiye sahip olmadı̆̆g görülmüşü̈r.
\end{abstract}

\section{INTRODUCTION}

Recent studies have revealed that point mutations, duplicationsand deletions occur in mitochondrial DNA's (mtDNAs) in different tissues of individuals (1-3). Most of the mtDNA mutations can affect very large base pairs. Among the deletions observed, mt4977 mutation, which is located at nucleotide positions $8470-8482$ and 13447-13459 and
Keywords: mtDNA4977 deletion Ischemic heart disease Platelet ATP

Anahtar Kelimeler: mtDNA 4977 delesyonu Iskemik kalp hastaliğ Trombosit ATP

Correspondence:Ahmet Özaydın, İstanbul Cerrahpaşa Üniversitesi Cerrahpasa Tıp Fakultesi, Tıbbi Genetik ABD, Prefabrik D Binası Fatih / Istanbul. Email: aozaydin@iuc.edu.tr

Cite as: Ozaydin A, Kerimova A, Onaran I. The Effects of mitochondrial mt4977 deletion on platelet function in 1schemic heart disease patients. Phnx Med J. 2021;3(2):54-58.

Received: 03.02.2021

Accepted: 22.02 .2021 


\section{Ozaydin et al.}

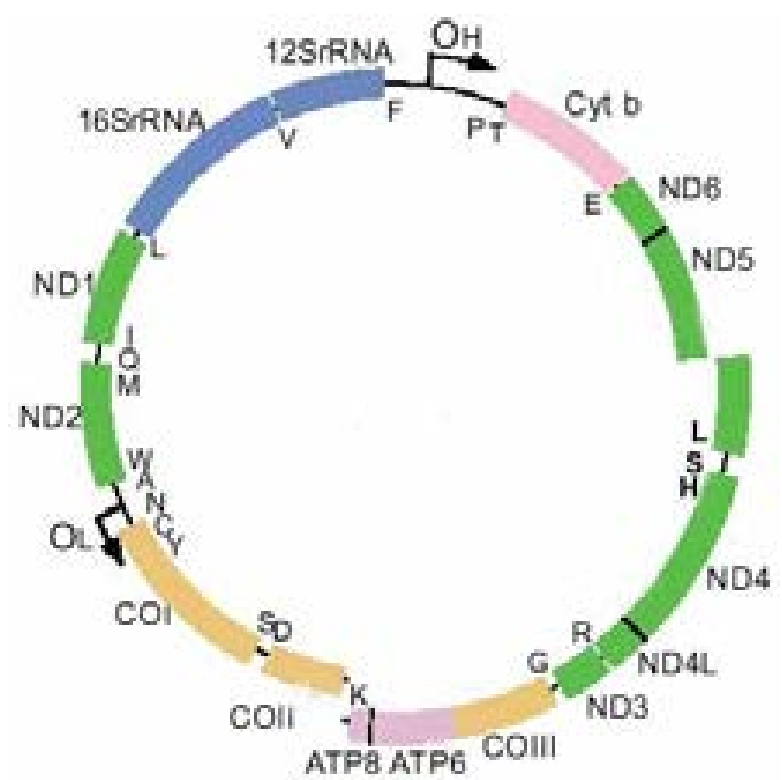

Figure 1: Mitochondrial 4977 bp deletion site.

the mitochondrial DNA chain and the 22 tRNAs involved in protein synthesis. The reason for the breakage of this sequence is that the 5'-CCAT-3' repeats near the cleavage sequences are sensitive regions for the formation of 8-hydroxy 2'-deoxyguanosine (8-OHDG) in various deletions (6). It is also influenced by the fact that, single stranded DNA sequences formed by separation of DNA double strands due to electronegativity and conformational changes are more prone to DNA rearrangements.

MtDNA 4977 deletion also causes the loss of 8 genes encoding subunits of respiratory chain complexes. Accordingly, the deletion may be expected to inhibit oxidative function and reduce the level of ATP production. Findings suggest that increased deletion affects ATP production, leading to functional disorders causing to cell death.

Mt4977 mutation frequency increases with age and exposure to free radicals $(7,8)$. The 4977 deletion differs significantly from other mitochondrial mutations. Because they are affected throughout the life, they cause diseases developing with time mostly in somatic cells. Among the diseases that mt4977 deletion increases are diabetes, Parkinson's, Kearns-Sayre Syndrome, Pearson's Syndrome and infertility. Mitochondrial deletion was detected in the muscles of patients with chronic progressive external ophthalmoplegia, Kearnes-Sayre syndrome and Pearsons syndrome. mtDNA4977 deletions are also observed in healthy humans (9-12).

Various substances are released from the granules by the adhesion of the platelets to the collagen tissue. ADP is afactor that stimulates platelets to reach the lesion area and form aggregation. An important progress during the substance release process is the shape changes in platelets, that is, the discoid thrombocytes take the shape of a sphere, and the formation of dendritic extensions (13). This process requires energy and is performed by platelet-contractile proteins. The initiation and regulation of the transformation process depends on the formation of prostaglandin and the levels of c-AMP and Ca. Therefore, any dysfunction that affects the production of ATP in platelets, may cause a problem in fulfilling platelets functions (14).
Thrombocytes also have mitochondria. Mitochondrial ATP production is known to play an important role in platelet functions. There are many studies on mt4977 deletion with blood. But, these studies were performed on leukocytes. There are studies showing that mtDNA 4977 deletion may increase in leukocytes due to various factors $(2,9,15)$. However, there are no studies investigating the amount of mtDNA 4977 deletion in platelets. Since platelet activation plays an important role in pathophysiology of the ischemic heart disease (IHD), we wished to discuss the relationship between platelet function and mtDNA 4977 deletion in IHD.

\section{MATERIAL AND METHOD}

Blood samples were collected from 20 patients who were diagnosed with IHD and 20 healthy control subjects (between 18-54 years of age). The study was approved by the Cerrahpasa Medical Faculty Ethics Committee (No: B.30.2.IST.0.30.90.00/35425). We aimed to investigate the relationship between mtDNA4977 and platelet function by performing platelet function tests after platelets were isolated pure from these blood samples. In the other part of our study, it was intended to determine the ATP production amounts and mitochondrial copy numbers in the platelets of the cases and to examine their possible effects on mtDNA 4977 deletion and mitochondrial fuction. Platelets were isolated from citrated blood samples and these isolated platelets were purified. Mitochondrial isolation was performed from the obtained thrombocytes. For this purpose, a certain number of cells were used for each individual. $1 \mathrm{ml}$ of homogenization buffer was added to these cells and centrifuged for 8 minutes at $2000 \mathrm{rpm}$ followed by 3 minutes in the ultrasonic bath. The supernatant was transferred to an eppendorf tube and centrifuged at $15000 \mathrm{rpm}$ for 5 minutes. The precipitate collected in the bottom of the tube was dissolved with homogenization buffer added with $1.5 \mathrm{ml}$ of $5 \%$ Percoll. After the tubes were centrifuged at $15000 \mathrm{rpm}$ for 5 minutes, the precipitate (mitochondrial fraction) collected on the bottom of the tube was dissolved in $1 \mathrm{ml}$ of PBS. (Homogenization buffer: $0.25 \mathrm{M}$ sucrose, $40 \mathrm{mM} \mathrm{KCl}, 2 \mathrm{mM}$ Ethylene-bis tetraacetic acid, $20 \mathrm{mM}$ Tris- $\mathrm{HCl}$ ( $\mathrm{pH} 7.2), 1 \mathrm{mg} / \mathrm{ml}$ BSA (Bovine Serum Albumin,Merck KgaA, Darmstadt, Germany)).

Platelet activity was measured using aggregometer (Whole-Blood Aggro-Meter Model 560 Chrono-Log Corporation, PA, USA). Optical aggregometers are modified spectrophotometric instruments. They work with the principle that when the platelet rich plasma (PRP) is mixed at a certain rate, the excitatory agent is added and the platelets form aggregates and the change in the light transmittance is measured. Blood samples were centrifuged at $150 \mathrm{~g}$ for $10 \mathrm{~min}$ to obtain PRP, and at $2000 \mathrm{~g}$ for $15 \mathrm{~min}$ further centrifugation to obtain platelet poor plasma (PPP). ADP $(10 \mu \mathrm{M}$, Chronolog Reagent) was used as stimulating agent.

After the calibration with $500 \mu \mathrm{l}$ PPP, $50 \mu \mathrm{l}$ of stimulant is added to $450 \mu \mathrm{l}$ of PRP with stirring magnet particle (stirring speed $1000 \mathrm{rpm}$ ) followed by the initiation of the aggregation process for 10 minutes. Experimental results are expressed as \% maximal aggregation, maximum aggregation reaching time $(\mathrm{sec})$ and lag time $(\mathrm{sec})$. 


\section{Phnx Med J. July 2021, Volume 3 No 2}

ATP measurement was performed with the bioluminescence assay kit CLS II (ATP Bioluminescence Assay Kit CLC II; Roche). ATP quantification in the platelets of the study groups was performed according to the manufacturer's recommended method. For each case, the experiment was repeated twice. For this, 1:9 boiled Tris-EDTA solution was added to $50 \mu \mathrm{L}$ platelet suspension and incubated at $+100^{\circ} \mathrm{C}$ for $2 \mathrm{~min}$. Centrifuged at $1000 \mathrm{x}$ g for $60 \mathrm{sec}$ and $50 \mu \mathrm{l}$ supernatant transferred to luminescence tubes. Chemiluminescence measurements were taken within 10 seconds by adding $50 \mu \mathrm{l}$ luciferase to the tubes. Blind measurement was done in the absence of ATP or cells. Amounts of ATP in the samples were calculated using the standard curve obtained from ATP concentrations increasing from $1 \mathrm{pM}$ to $1 \mathrm{mM}$. The results were calculated as $\mathrm{nM} / \mathrm{mg}$ protein.

Detection of mtDNA 4977 deletion copy number by RTPCR:

MtDNA 4977 deletion (between 8.470-13.447 bp), which is one of the major deletions of the mitochondrial genome, was determined by the simultaneous quantitative polymerase chain reaction method modified for platelets. Samples suitable for measuring mt4977 deletion from DNA samples were analyzed with Real time PCR device (Qiagen Rotor Gene 6000) using SYBR green dye. In order to prepare DNA fragments that will represent the total mtDNA, primers were designed with the help of a database from sequences (GenBANK Accesion No NC001807 and the MITOMAP database), which are accepted as a region closed to deletion in mitochondrial DNA $(16,17)$. This region is generally not open to deletion, primers representing the dmtDNA 4977 deletion are from regions located outside of the break sequences (regions sensitive to the formation of 5'-CCAT-3 'repeating sequences 8-hydroxy 2'- deoxyguanizine (8-OHdG)) and $5 \mathrm{~kb}$. (4977 bp deletion is about $5 \mathrm{~kb}$ in size) was chosen to contain no sequences of the deletion. The region representing the deletion is named $\mathrm{mtD}$ NA 4977. The deleted mtDNA is restored because it is a circular DNA. Linking of these available primers can only occur when the deletion is present. In the absence of deletion mitochondria, it is not possible to reproduce the region with a size of $5 \mathrm{~kb}$ under PCR conditions. External standard curves were used to find the unknown amount of mt4977 in the sample. Therefore, in our study, plasmids containing both mtDNA 4977 deletion and total mtDNA were prepared and standardization was calculated according to the serial dilutions of each primer. For the preparation of the standard curve, the region cloned into the pGEM vector (representing the deletion) and the region representing the total mtDNA were used. Each measure- ment was done twice and normalized against a serial dilution of the corresponding plasmid clones with a known amount of input copy number and then the quantity of each target gene in our samples was calculated according to the corresponding standard curve. For both primary product was made its self calculation standards. It was calculated using the site https://cels.uri.edu/gsc/cndna.html to determine the number of copies from the data we obtained.

Statistical Analysis:

GraphPad Prism 6 program was used for statistical analysis of the experimental results. Paired comparisons of the groups were made with the Mann Whitney U test and the differences between the groups were analyzed. $\mathrm{p}<0.05$ was considered statistically significant.

\section{RESULTS}

Platelet functions were studied by giving ADP stimulus with lumiaggregometer device to evaluate in terms of secretion and aggregation. IHD and control groups were evaluated in terms of slope $(\Omega)$ and amplitude $\%$, which are two measures of platelet aggregation curve, and there was no statistically significant difference between IHD and control groups in terms of slope $(\Omega)$ and amplitude \% values. Slope $(p=0.53)$ Amplitude $(p=0.06)$. Although the slope was higher in the IHD group compared to the control group, it did not show any statistical significance. The amplitude \% values were higher in the control group than in the IHD group (Table 1).

In the study, intra-platelet ATP levels were determined by chemiluminometric method. When ATP levels were evaluated independent of deletion rate between two groups, no statistically significant difference was observed ( $\mathrm{p}>0.05)$. ATP levels in the control group; mean \pm SD: $24.15 \pm 4.38$, in the IHD group: $20.00 \pm 4.73$. The coefficient of variation rates $(\mathrm{CV})$ were $18.14 \%$, respectively; It has been calculated as $23.68 \%$.

However, there was a correlation between ATP levels and deletion rates. Although there was no correlation in terms of two parameters in the control group, there was a significant relationship in the patient group. Despite the presence of deletion cases in the control group, the lack of a complete relationship between ATP levels and deletion levels suggests that other factors also keep ATP levels high.

RT PCR Analysis of Deleted dmtDNA4977 Quantities: Using the real-time PCR technique, the most convenient way to find the unknown amount of mtDNA 4977 in a sample is to use external standard curves. In our study, plasmids containing mtDNA 4977 and total mtDNA were prepared. According to the analysis results, observed that fluorescence curves showing the presence of dmtDNA 4977 and total mtDNA were formed in all samples. These

Table 1: Comparison of platelet aggregation slope $(\Omega)$ and platelet aggregation amplitude \% values in IHD and control groups.

\begin{tabular}{|c|c|c|c|c|c|}
\hline & $\begin{array}{c}\text { IHD } \\
\operatorname{Avg} \pm \text { Std (n=20) }\end{array}$ & CV & $\begin{array}{c}\text { Control } \\
\operatorname{Avg} \pm \operatorname{Std}(n=20)\end{array}$ & CV & p Value \\
\hline $\begin{array}{l}\text { Platelet } \\
\text { aggregation } \\
\text { SLOPE }(\Omega)\end{array}$ & $116.90 \pm 28.21$ & 24.12 & $113.90 \pm 35.16$ & 30.88 & 0,526 \\
\hline $\begin{array}{l}\text { Platelet } \\
\text { aggregation } \\
\text { AMPLITUDE\% }\end{array}$ & $66.51 \pm 25.18$ & 37.86 & $74.73 \pm 30.71$ & 41.09 & 0,056 \\
\hline
\end{tabular}




\section{Ozaydin et al.}

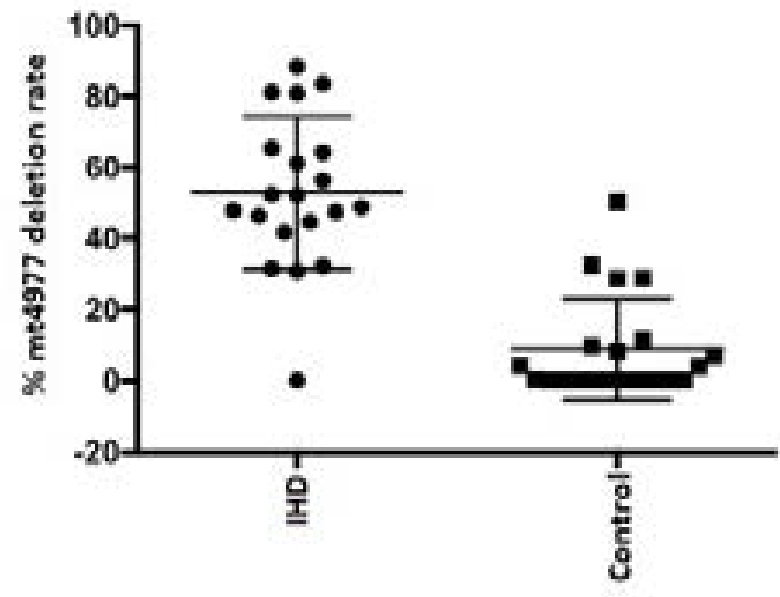

Groups

Figure 2: \% mt4977 deletion rate: The amount of deletion was calculated according to the dmtDNA4977 copy / mtDNA copy number and is given as \%. Groups: IHD (Ischemic heart disease), control (healthy individuals). The mean $\pm \mathrm{SD}$ values of the relevant group are shown on the graphs.

results show that 4977 bp deletions were positive in all studied platelet samples. The mtDNA 4977 / total mtDNA copy number ratios of these groups were calculated, and paired comparisons of the groups were made using the Mann Whitney U test. Control group had less mtDNA 4977 deletion than IHD patients $(\mathrm{p}<0.0001)$. Change coefficient values of groups; $160 \%$ for controls and $40 \%$ for IHDs.

Analysis of Mitochondrial DNA Copy Number by RTPCR:

External standard curves were prepared as previously described to find the total amount of mtDNA in a sample using the real-time PCR technique. For this, plasmids containing the total mtDNA gene were prepared. When the total mtDNA copy number of these groups are calculated and the paired comparisons of the groups are made using the Mann Whitney U test, the IHD group has a significantly higher amount of mitochondrial DNA copy numbers $(\mathrm{p}<0.0001)$ compared to the control group (Figure 2, 3).

The coefficient of change values of the groups were calculated as $260 \%$ for control and $61 \%$ for IHD.

The relationship between the mitochondrial deletion rates of the patient and control groups and the amount of ATP in thrombocytes was investigated by nonparametric Spearman correlation. When the \% mitochondrial deletion of the control group is compared with the amount of ATP, it is seen that there is a low correlation ( $\mathrm{r}: 0.051)$ and there is no significant difference $(\mathrm{p}>0.05)$. On the other hand, when the $\%$ mitochondrial deletion rate of the IHD patient group is compared with the amount of ATP in platelets, it is understood that there is a significant reverse correlation (r: -0.70) and a statistically significant difference $(\mathrm{p}<0.005)$ (Figure 4).

\section{DISCUSSION}

mtDNA 4977 deletion causes the loss of 8 genes encoding subunits of the respiratory chain complexes. Mitochondrial deletion may inhibit oxidative phosphorylation and the electron transport chain, increase the level of oxidative

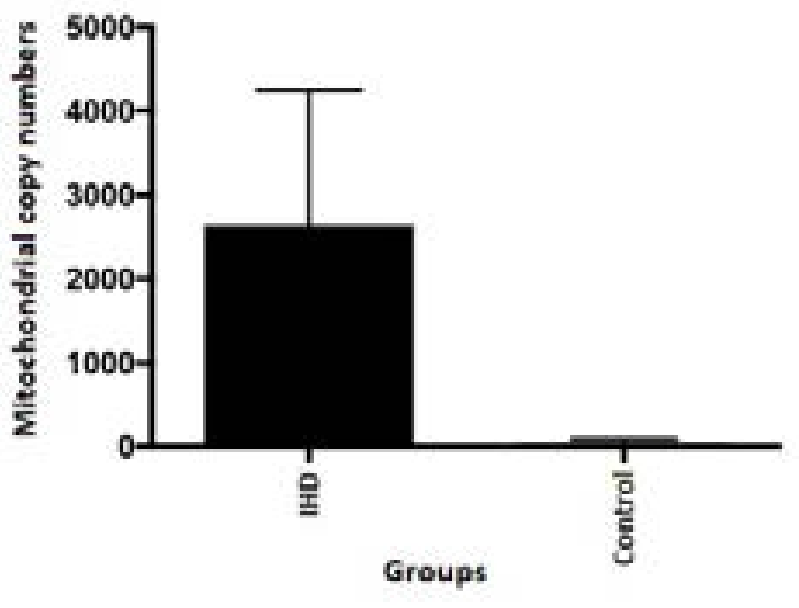

Figure 3: Mitochondrial copy numbers: Comparison of mitochondrial copy numbers between IHD and Control groups. Data are given as copy amount. The mean \pm SD values of the relevant group are given on the graphics.

stress, and result in ROS accumulation. As a result, inhibits oxidative function and can cause a decrease in the level of ATP production. There are many evidences that the increased deletion rate affects ATP production and causes functional disorders leading to cell death $(5,18,19)$. Our results show that this same situation is also valid for thrombocytes, and IHD patients, in which thrombocyte activation plays an important role in IHD physiopathology, are affected more than healthy individuals. Especially, the detection that individuals with high mitochondrial deletion rates according to their total copy number have a higher reduction in ATP amounts in their platelets compared to the control group supports this finding. On the other hand, mtDNA 4977 deletion is also seen in healthy people. Although there are cases with deletions in the control group, the lack of a complete relationship between ATP levels and deletion levels indicates that other factors also keep ATP levels high. mtDNA 4977 deletion is also encountered in some other diseases. The finding that mtDNA 4977 accumulates with age is controversial. Von Wurmb $\mathrm{N}$ et al. suggested that this deletion increases with age (20), and others reported that it is associated with the occurrence of

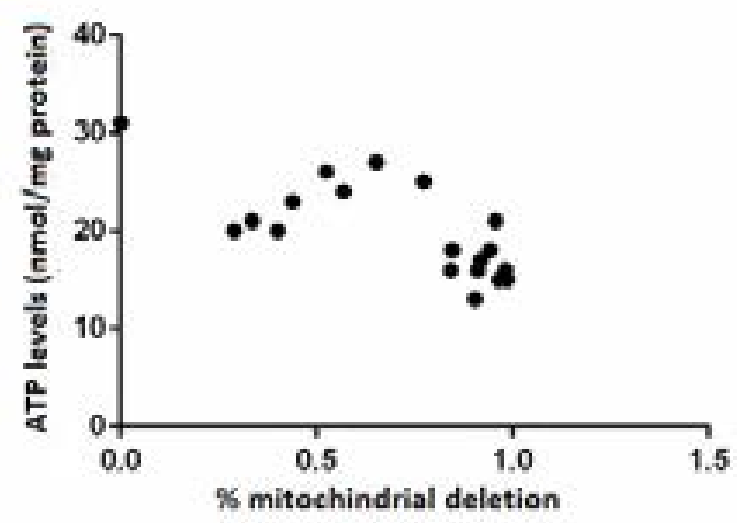

Figure 4: Correlation between \% mitochondrial deletion rate and ATP amounts in platelets belonging to IHD patient group. 


\section{Phnx Med J. July 2021, Volume 3 No 2}

various types of degenerative diseases and aging $(21,22)$. In order to ensure normal mitochondrial function, the organism increases the total mtDNA copy number in order to maintain normal mtDNA copy number, especially in organs with high oxygen requirement such as brain and muscle (19).

Therefore, more research is needed to assign the impact of this condition on mitochondrial dysfunction and hence ischemic heart disease. However; our study is one of the pioneering studies on platelets in this field. We think that our findings will contribute to the elucidation of cellular energy deficiency diseases such as IHD and possible treatment approaches.

Conflict of Interest: No conflict of interest was declared by the authors.

Acknowledgments: This research was financially supported by Istanbul University-Cerrahpaşa Scientific Research Projects Coordination Unit (Project No: 770/30498).

\section{REFERENCES}

1. Sherratt EJ, Thomas AW, Alcolado JC. Mitochondrial DNA defects: a widening clinical spectrum of disorders. Clin Sci (Lond). 1997;92(3):225235. DOI:10.1042/cs0920225

2. Mohamed SA, Wesch D, Blumenthal A, Bruse P, Windler K, Ernst M, et al. Detection of the 4977 bp deletion of mitochondrial DNA in different human blood cells. Exp Gerontol. 2004;39:181-8. DOI: 10.1016/j.exger.2003.10.011.

3. Hu H, Lin Y, Xu X, Lin S, Chen X, Wang S. The alterations of mitochondrial DNA in coronary heart disease. Exp Mol Pathol. $2020 ; 114: 104412$. DOI: $10.1016 /$ j.yexmp.2020.104412.

4. Chen T, He J, Shen L, Fang H, Nie H, Jin T, Wei X, Xin Y, Jiang Y, Li H, Chen G, Lu J, Bai Y. The mitochondrial DNA 4,977-bp deletion and its implication in copy number alteration in colorectal cancer. BMC Med Genet. 2011 Jan 13;12:8. DOI: 10.1186/1471-2350-12-8.

5. Yusoff AAM, Abdullah WSW, Khair SZNM, Radzak SMA. A comprehensive overview of mitochondrial DNA 4977-bp deletion in cancer studies. Oncol Rev. 2019;13(1):409. DOI:10.4081/oncol.2019.409

6. Kakimoto M, Inoguchi T, Sonta T, et al. Accumulation of 8-hydroxy-2'-deoxyguanosine and mitochondrial DNA deletion in kidney of diabetic rats. Diabetes. 2002;51(5):1588-1595. doi:10.2337/diabetes.51.5.1588

7. Wei YH, Wu SB, Ma YS, Lee HC. Respiratory function decline and DNA mutation in mitochondria, oxidative stress and altered gene expression during aging. Chang Gung Med J. 2009;32:113-32.

8. Zabihi Diba L, Mohaddes Ardebili SM, Gharesouran J, Houshmand M. Age-related decrease in mtDNA content as a consequence of mtDNA 4977 bp deletion. Mitochondrial DNA A DNA Mapp Seq Anal. 2016 Jul;27(4):3008-3012. DOI: 10.3109/19401736.2015.1063046.

9. Malik AN, Czajka A. Is mitochondrial DNA content a potential biomarker of mitochondrial dysfunction? Mitochondrion. 2013 Sep;13(5):481-92. DOI: $10.1016 /$ j.mito.2012.10.011.

10. Huang YH, Chen CM, Lee YS, Chang KH, Chen HW, Chen YC. Detection of mitochondrial DNA with 4977 bp deletion in leukocytes of patients with ischemic stroke. PLoS One. 2018 Feb 23;13(2):e0193175. DOI: 10.1371/journal.pone.0193175.

11. Talebi E, Karimian M, Nikzad H. Association of sperm mitochondrial DNA deletions with male infertility in an Iranian population. Mitochondrial DNA A DNA Mapp Seq Anal. 2018 May;29(4):615-623. DOI: 10.1080/24701394.2017.1331347.

12. Bacalhau M, Simões M, Rocha MC, Hardy SA, Vincent AE, Durães J, et al. Disclosing the functional changes of two genetic alterations in a patient with Chronic Progressive External Ophthalmoplegia: Report of the novel mtDNA m.7486G $>$ A variant. Neuromuscul Disord. 2018 Apr;28(4):350-360. DOI: 10.1016/j.nmd.2017.11.006.

13. Daniel JL, Dangelmaier C, Jin J, Ashby B, Smith JB, Kunapuli SP. Molecular basis for ADP-induced platelet activation. I. Evidence for three distinct ADP receptors on human platelets. J Biol Chem. 1998 Jan 23;273(4):2024-9. doi: 10.1074/jbc.273.4.2024.

14. Collins AS. Pivotal role of platelets in critical illness: evidence behind clinical interventions. Dimens Crit Care Nurs. 2004;23(5):217-221. DOI:10.1097/00003465-200409000-00006.

15. Vecoli C, Borghini A, Pulignani S, Mercuri A, Turchi S, Carpeggiani C, et al. Prognostic value of mitochondrial DNA4977 deletion and mitochondrial DNA copy number in patients with stable coronary artery disease. Atherosclerosis. 2018 Sep;276:91-97. DOI: 10.1016/j.atherosclerosis.2018.07.015.

16. Lott MT, Leipzig JN, Derbeneva O, Xie HM, Chalkia D, Sarmady M, et al. mtDNA Variation and Analysis Using Mitomap and Mitomaster. Curr Protoc Bioinformatics. 2013 Dec;44(123):1.23.1-26. DOI: 10.1002/0471250953.bi0123s44.

17. Ye C, Shu XO, Wen W, Pierce L, Courtney R, Gao YT, et al. Quantitative analysis of mitochondrial DNA 4977-bp deletion in sporadic breast cancer and benign breast diseases. Breast Cancer Res Treat. 2008 Apr;108(3):427-34. DOI: 10.1007/s10549-007-9613-9.

18. Meissner C, Bruse P, Mohamed SA, Schulz A, Warnk H, Storm T, et al. The 4977 bp deletion of mitochondrial DNA in human skeletal muscle, heart and different areas of the brain: a useful biomarker or more? Exp Gerontol. 2008 Jul;43(7):645-52. DOI: 10.1016/j.exger.2008.03.004.

19. Zhang Y, Ma Y, Bu D, Liu H, Xia C, Zhang Y,et al. Deletion of a 4977-bp Fragment in the Mitochondrial Genome Is Associated with Mitochondrial Disease Severity. PLoS One. 2015 May 29;10(5):e0128624. DOI: 10.1371/journal.pone.0128624.

20. von Wurmb N, Schwark T, Caliebe A, Drenske C, Nikolaus S, Screiber S, et al. Low level of the mtDNA4977 deletion in blood of exceptionally old individuals. Mech Ageing Dev. 2010; 131: 179-184. DOI: 10.1016/j.mad.2010.01.005.

21. Shao JY, Gao HY, Li YH, Zhang Y, Lu YY, Zeng YX. Quantitative detection of common deletion of mitochondrial DNA in hepatocellular carcinoma and hepatocellular nodular hyperplasia. World J Gastroenterol. 2004; 10: 1560-1564.

22. Nie HZ, Shu HY, Vartak R, Milstein AC, Mo Y, Hu X, et al. Mitochondrial common deletion, a potential biomarker for cancer occurrence, is selected against in cancer background: a meta-analysis of 38 studies. PLOS One. 2013; 8: e67953. DOI: 10.1371/journal.pone.0067953. 